\title{
Recurrent Stereotyped Episodes in Cerebral Amyloid Angiopathy: Response to Migraine Prophylaxis in Two Patients
}

\author{
R.W. Paterson ${ }^{a} \quad$ K. Uchino ${ }^{d} \quad$ H.C. Emsley ${ }^{b}$ P. Pullicino ${ }^{c}$ \\ ${ }^{a}$ National Hospital for Neurology and Neurosurgery, London, ${ }^{b}$ Department of Neurology, \\ Royal Preston Hospital, Preston, and ${ }^{\mathrm{C} E a s t ~ K e n t ~ H o s p i t a l s ~ N H S ~ F o u n d a t i o n ~ T r u s t, ~}$ \\ Canterbury, UK; ${ }^{d}$ Cerebrovascular Center, Cleveland Clinic, Cleveland, Ohio, USA
}

Key Words

Recurrent stereotyped episodes · Cerebral amyloid angiopathy · Migraine prophylaxis

\begin{abstract}
Background: Cerebral amyloid angiopathy (CAA) typically presents with cognitive decline or symptomatic intracerebral hemorrhage, but episodes of recurrent stereotyped limb attacks have also been reported. Methods: Retrospective review of the medical records of 4 patients referred to the general neurology services and a specialist stroke center with clinically probable CAA. Results: Four subjects, all Caucasian, mean age 74 years, were followed up over a mean duration of 20 months. They all experienced recurrent prolonged stereotyped attacks of sensory symptoms, lasting 5-30 min, that resolved completely between attacks. Three subjects developed intracerebral hemorrhage, and 2 had an irreversible rapid cognitive decline. Two patients experienced symptomatic improvement with migraine prophylaxis (verapamil or topiramate). Conclusions: Recurrent stereotyped prolonged attacks with sensory and motor elements can predate the development of intracerebral hemorrhage in individuals with clinically probable CAA. When evaluating patients with such attacks, neurologists need to consider CAA as a possible mimic of transient ischemic attacks. We suggest a trial of migraine prophylaxis for symptomatic management.

Copyright (c) 2013 S. Karger AG, Basel
\end{abstract}

\section{Introduction}

Cerebral amyloid angiopathy (CAA) typically presents with cognitive decline or symptomatic intracerebral hemorrhage, but episodes of recurrent stereotyped limb attacks have also been reported [1,2]. We describe 4 patients with probable CAA on MRI, with recurrent frequent migraine-like episodes over a period of weeks to months, 2 of whom responded to migraine prophylaxis and a third who responded to antiplatelet withdrawal. 


\section{Case 1}

A 74-year-old woman presented with 3 weeks of stereotyped episodes of tingling and numbness, starting in her right arm and spreading within minutes to contiguous body parts until the face, arm and leg were involved. She had had 5-7 events per day for 3 years. Exam was normal. EEG was normal. MRI showed subcortical hemosiderin deposits on gradient echo sequences (GRE) typical of CAA. Topiramate $25 \mathrm{mg}$ twice daily terminated the attacks.

\section{Case 2}

A 72-year-old woman had an 8-week history of colorful flashes of different jagged shapes including pinwheels throughout both visual fields lasting up to 30 min between 5 and 10 times per day. Exam was normal. The episodes completely resolved on verapamil $240 \mathrm{mg}$ a day. Four months later, she blacked out while driving and 3 days later 'lost her color vision'. CT showed an acute right occipital hemorrhage. Color vision returned 4 days later. The visual phenomena recurred but were reduced in frequency on verapamil $120 \mathrm{mg}$. MRI GRE showed multiple focal areas of subcortical hemosiderin typical for CAA.

\section{Case 3}

An 81-year-old woman presented with a 2-month history of recurrent 5-min episodes of left hand and arm numbness and leg weakness, later evolving to attacks including speech. Exam was normal. MRI showed areas of subcortical hemosiderin on GRE. One month later, she developed sudden cognitive impairment. MRI showed a right temporal lobe intraparenchymal hemorrhage and edematous T2 lesions in both occipital lobes. Transient left-sided sensory symptoms continued, less frequently, for 2 months and then stopped completely. They have not recurred for 24 months.

\section{Case 4}

A 70-year-old woman presented with 18 months of stereotyped episodes of altered sensation in the right or left side. Paresthesia spread slowly within minutes to involve contiguous body parts. Attacks involved the face, arm, leg and tongue, lasted $30 \mathrm{~min}$ and occurred up to 3 times per week. EEG demonstrated bilateral frequent irregular slow wave activity with sharp components. MRI performed 18 months after symptom onset showed a small $(1.3 \mathrm{~cm})$ intraparenchymal hemorrhage in the right parietal lobe. GRE showed decreased superficial cortical signals probably due to hemosiderin deposition, and numerous dark foci suggestive of microhemorrhages predominantly in cortico-subcortical distribution. The attacks increased in frequency and severity after aspirin and dipyridamole were commenced as a treatment for presumed transient ischemic attack (TIA). When antiplatelets were discontinued, the attacks terminated within weeks. This case has previously been published [3].

Clinical summaries of all 4 cases are given in table 1 . 


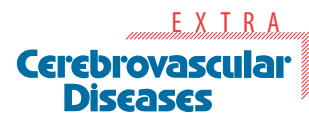

\begin{tabular}{l|l}
\hline \multicolumn{2}{l}{ Cerebrovasc Dis Extra 2013;3:81-84 } \\
\hline DOI: $10.1159 / 000347114$ & $\begin{array}{l}\text { C 2013 S. Karger AG, Basel } \\
\text { www.karger.com/cee }\end{array}$ \\
\hline
\end{tabular}

Paterson et al.: Recurrent Stereotyped Episodes in Cerebral Amyloid Angiopathy:

Response to Migraine Prophylaxis in Two Patients

Table 1. Summary of the clinical and radiological features

\begin{tabular}{|c|c|c|c|c|}
\hline & Patient 1 & Patient 2 & Patient 3 & Patient 4 \\
\hline Age at onset, years & 74 & 71 & 81 & 70 \\
\hline Ethnicity & Caucasian & Caucasian & Caucasian & Caucasian \\
\hline Event type & $\begin{array}{l}\text { Face and limb } \\
\text { numbness }\end{array}$ & $\begin{array}{l}\text { Visual disturbance (bright } \\
\text { lights and pinwheeling) }\end{array}$ & $\begin{array}{l}\text { Upper limb numbness and } \\
\text { dysphasia }\end{array}$ & $\begin{array}{l}\text { Face, tongue, arm and } \\
\text { leg paresthesia and } \\
\text { dysphasia }\end{array}$ \\
\hline Headache & No & No & No & No \\
\hline Lateralization & Unilateral & Bilateral & Bilateral & $\begin{array}{l}\text { Unilateral, affecting } \\
\text { either side }\end{array}$ \\
\hline Event frequency & $\begin{array}{l}5-7 \text { attacks/day } \\
\text { For } 3 \text { years }\end{array}$ & $\begin{array}{l}5-10 \text { attacks/day } \\
\text { For } 1 \text { year }\end{array}$ & $\begin{array}{l}10 \text { attacks/month } \\
\text { For } 2 \text { months }\end{array}$ & $\begin{array}{l}12 \text { attacks/month } \\
\text { For } 18 \text { months }\end{array}$ \\
\hline Event duration & $20-30 \mathrm{~min}$ & $30 \mathrm{~min}$ & $5 \mathrm{~min}$ & $30 \mathrm{~min}$ \\
\hline Vascular status & $\begin{array}{l}\text { Hypercholesterolemia } \\
\text { on statin } \\
\text { Hypertension, } \\
\text { non-insulin-dependent } \\
\text { diabetes mellitus } \\
\text { Never smoked }\end{array}$ & $\begin{array}{l}\text { Never smoked } \\
\text { No vascular risk factors }\end{array}$ & $\begin{array}{l}\text { Hypercholesterolemia on } \\
\text { statin } \\
\text { Never smoked } \\
\text { No other vascular risk } \\
\text { factors }\end{array}$ & $\begin{array}{l}\text { Never smoked } \\
\text { No other vascular risk } \\
\text { factors }\end{array}$ \\
\hline History of migraine & No & No & No & No \\
\hline Clinical sequelae & $\begin{array}{l}\text { Progressive cognitive } \\
\text { decline over } 1 \text { year }\end{array}$ & $\begin{array}{l}\text { Symptomatic intracerebral } \\
\text { hemorrhage (right occipital } \\
\text { lobe) after } 9 \text { months }\end{array}$ & $\begin{array}{l}\text { Symptomatic intracerebral } \\
\text { hemorrhage (right temporal } \\
\text { lobe) after } 1 \text { month with } \\
\text { rapid cognitive decline over } \\
\text { hours }\end{array}$ & $\begin{array}{l}\text { Asymptomatic } \\
\text { intracerebral } \\
\text { hemorrhage (right } \\
\text { parietal lobe) }\end{array}$ \\
\hline $\begin{array}{l}\text { Response to } \\
\text { treatment }\end{array}$ & $\begin{array}{l}\text { Completely terminated } \\
\text { with topiramate } 25 \mathrm{mg} \\
\text { b.d. } \\
\text { Followed up for } 9 \\
\text { months }\end{array}$ & $\begin{array}{l}\text { Frequency reduced on } \\
\text { verapamil } 120 \mathrm{mg} / \text { day } \\
\text { Completely terminated with } \\
\text { verapamil } 240 \mathrm{mg} / \text { day }\end{array}$ & $\begin{array}{l}\text { Spontaneous resolution of } \\
\text { focal neurological spells } \\
\text { following symptomatic } \\
\text { hemorrhage }\end{array}$ & $\begin{array}{l}\text { Completely terminated } \\
\text { weeks after } \\
\text { withdrawing aspirin } \\
\text { and clopidogrel } \\
\text { Followed up for } 2 \text { years }\end{array}$ \\
\hline MRI (GRE) & $\begin{array}{l}\text { Microhemorrhages in } \\
\text { subcortical regions }\end{array}$ & $\begin{array}{l}\text { Microhemorrhages in } \\
\text { subcortical regions }\end{array}$ & $\begin{array}{l}\text { Microhemorrhages in } \\
\text { cortical and subcortical } \\
\text { regions } \\
\text { Right temporal hematoma }\end{array}$ & $\begin{array}{l}\text { Microhemorrhages in } \\
\text { cortical and subcortical } \\
\text { regions }\end{array}$ \\
\hline
\end{tabular}

\section{Discussion}

All 4 of our patients have probable CAA according to the Boston criteria [4]. All 4 patients had frequent stereotyped attacks over a prolonged period of time (mean 4 weeks, range 3-74 weeks). These attacks occurred over a much longer period and were more frequent and stereotyped than attacks previously reported with CAA without or with associated subarachnoid hemorrhage $[1,2]$. The attacks had a time course similar to a migraine aura with symptoms spread over several minutes. The frequent and stereotypic nature of the attacks led to a diagnosis of TIA in 1 patient with initiation of antiplatelet treatment.

The development of these attacks may be a predictor of future symptomatic intracerebral hemorrhage, as it occurred in 2 of our 4 patients at 1 and 9 months after the onset of symptoms. Patient 2 who had recurrent positive visual phenomena had subsequent symptomatic occipital hemorrhage. Patient 3 with numbness starting in her left hand subsequently developed right temporal hemorrhage. She also developed concurrent edematous lesions consistent with the 'inflammatory' form of amyloid angiopathy, also known as reversible leukoencephalopathy [5]. Patient 4 had an asymptomatic intracerebral hemorrhage.

The duration of the attacks was similar to a migraine aura, and the response to migraine prophylactics supports a 'spreading depression' pathogenesis rather than transient ischemia; 
we therefore propose the name 'transient aura attacks'. We hypothesize that these attacks may be initiated by cortical irritation or inflammation caused by blood products or edema from prior cortical hemorrhage, as the disruption of pial arterial walls in CAA is known to cause small focal hemorrhages. These attacks may also herald cerebral hemorrhage. The clinical distinction of these attacks from TIAs is important, as antiplatelet agents [6] and anticoagulation $[7,8]$ are likely to increase the risk of hemorrhage.

\section{Disclosure Statement}

Dr. Pullicino received honoraria as a consultant for Merck and Boehringer Ingelheim. Dr. Paterson, Dr. Uchino and Dr. Emsley have no declarations to make.

\section{References}

1 Izenberg A, Aviv RI, Demaerschalk BM, Dodick DW, Hopyan J, Black SE, Gladstone DJ: Crescendo transient Aura attacks: a transient ischemic attack mimic caused by focal subarachnoid hemorrhage. Stroke 2009;40:37253729.

-2 Greenberg SM, Vonsattel JP, Stakes JW, Gruber M, Finklestein SP: The clinical spectrum of cerebral amyloid angiopathy: presentations without lobar hemorrhage. Neurology 1993;43:2073-2079.

-3 Emsley HCA, Kowalewska-Zietek J, Gulati RS, Wuppalapati S: When stopping the antiplatelet drugs stopped the 'TIAs'. Pract Neurol 2012;12:36-39.

4 Knudsen KA, Rosand J, Karluk D, Greenberg SM: Clinical diagnosis of cerebral amyloid angiopathy: validation of the Boston criteria. Neurology 2001;56:537-539.

-5 Oh U, Gupta R, Krakauer JW, Khandji AG, Chin SS, Elkind MS: Reversible leukoencephalopathy associated with cerebral amyloid angiopathy. Neurology 2004;62:494-497.

6 Biffi A, Halpin A, Towfighi A, Gilson A, Busl K, Rost N, Smith EE, Greenberg MS, Rosand J, Viswanathan A: Aspirin and recurrent intracerebral hemorrhage in cerebral amyloid angiopathy. Neurology 2010;75:693698.

7 Charidimou A, Shakeshaft C, Werring DJ: Cerebral microbleeds on magnetic resonance imaging and anticoagulant-associated intracerebral hemorrhage risk. Front Neurol 2012;3:133.

-8 Melo TP, Bogousslavsky J, Regli F, Janzer R: Fatal hemorrhage during anticoagulation of cardioembolic infarction: role of cerebral amyloid angiopathy. Eur Neurol 1993;33:9-12. 